\title{
Functional analysis of NTF-1, a developmentally regulated Drosophila transcription factor that binds neuronal cis elements
}

\author{
Brian David Dynlacht, Laura D. Attardi, Arie Admon, Matthew Freeman, and Robert Tjian \\ Howard Hughes Medical Institute, Department of Molecular and Cell Biology, University of California at Berkeley, Berkeley, \\ California 94720 USA
}

\begin{abstract}
In an effort to characterize sequence-specific transcription factors that regulate gene expression during Drosophila development, we identified and purified a novel DNA-binding activity (NTF-1). The purified protein consists of several polypeptides that bind selectively to a functionally important cis-control element of the Ultrabithorax $(U b x)$ promoter and to the neurogenic elements of both the dopa decarboxylase $(D d c)$ and fushi tarazu (ftz) promoter/enhancer regions. Purified NTF-1 activates transcription in vitro in a binding sitedependent manner through upstream sequences of the $U b \times$ promoter. A cDNA clone encoding the open reading frame of NTF-1 was isolated, and the deduced primary amino acid sequence of NTF-1 includes a glutamine-rich region reminiscent of the transcriptional activation domains found in Sp1 but no recognizable DNA-binding domain. NTF-1 expression is temporally regulated during embryonic development. In addition, in situ hybridization experiments revealed that NTF-1 is transcribed in a spatially restricted pattern in the embryo, with the highest level of expression observed in the epidermis and a subset of cells in the CNS. Expression of the NTF-1 cDNA in mammalian cells yields a protein that displays DNA-binding and transcriptional activities indistinguishable from that of the collection of proteins isolated from Drosophila embryos. These findings suggest that NTF-1 is a member of a family of developmentally regulated transcription factors that may be involved in directing the expression of genes such as $U b x, D d c$, and $\mathrm{ftz}$ in neuronal cells.
\end{abstract}

[Key Words: $U b x$; neurogenic element; transcription in vitro; cell-type specificity; developmental control]

Received July 19, 1989; revised version accepted August 24, 1989.

The intricate patterns of transcription during development and differentiation of higher eukaryotes require the concerted interplay of multiple regulatory proteins that govern initiation of mRNA synthesis in the cell nucleus. We chose Drosophila as a model system for studying temporally programmed and spatially restricted transcription during embryogenesis because genetic analysis has already identified an extensive network of control genes that determine cellular fates during development. Of the many developmentally regulated genes in Drosophila, the homeotic gene Ultrabithorax $(U b \mathrm{x})$ provides an attractive case for detailed biochemical analysis, because a number of regulatory factors that govern $U b x$ transcription, including other homeo domain proteins, have already been identified. In addition, several promoter-selective transcription factors, such as the GAGA and zeste proteins, which bind and selectively activate the $U b x$ promoter in vitro, have been isolated by direct biochemical fractionation of embryonic extracts (Biggin and Tjian 1988; Biggin et al. 1988).

As expected, most of the genes that control the ex- pression of $U b x$ are regulated during embryogenesis, themselves. However, not all of the transcription factors governing $U b x$ expression are developmentally controlled. For example, although the levels of expression of GAGA factor and zeste protein vary considerably during development, the proteins do not appear to be restricted to a single type of tissue in the embryo (Pirrotta et al. 1988; W. Soeller, pers. comm.). Instead, these proteins appear to be transcription factors that are expressed in a wide variety of cells in the fly and may act in concert with specific promoter factors to regulate many different classes of genes, including those expressed in a temporally and spatially restricted pattern in the embryo. In contrast, one of the DNA-binding activities detected originally by DNase I footprint protection of the $U b x$ promoter was found only in extracts derived from Drosophila embryos at certain developmental stages but not in Kc tissue culture cells (Biggin and Tjian 1988). Moreover, deletion of the cis element recognized by this embryo-specific binding activity resulted in a marked reduction in $U b x$ transcription when assayed in vitro with staged embryo nuclear extracts. Interestingly, the 
binding site on the $U b x$ template for this embryonic factor showed some homology to multiple cis-control elements in both the dopa decarboxylase $(D d c)$ and fushi tarazu $(f t z)$ promoter/enhancer sequences that have been reported to confer expression in neuronal cells (Bray et al. 1988; Hiromi et al. 1985). Thus, it is possible that this specific DNA-binding factor is involved in mediating the expression of $U b x$ in a subset of cells, such as those of the central nervous system (CNS). These findings prompted us to purify and characterize this putative cell-type-specific factor, which we designated as neurogenic element-binding transcription factor (NTF-1).

Here we report the purification of NTF-1 from Drosophila embryos by DNA affinity chromatography. The purified proteins were subsequently tested for their ability to bind $U b x, D d c$, and $f t z$ control elements and to activate transcription in reconstituted in vitro reactions directed by wild-type and mutant $U b x$ templates. The purified proteins were also used to generate partial amino acid sequence, which allowed us to obtain several oligonucleotide DNA probes to screen a cDNA library for sequences encoding NTF-1. A cDNA encoding an extended open reading frame (ORF) matching the amino acid sequences of the peptides was isolated and characterized. The temporal program of NTF-1 mRNA synthesis during embryogenesis and the spatially restricted pattern of expression in the embryo were determined. Finally, large quantities of NTF-1 were obtained by overproduction in mammalian cells through the use of vaccinia virus expression vectors, and the biochemical activities of the purified protein were characterized. These studies provide us with direct evidence pertaining to both the structural and functional properties of a celltype-specific Drosophila transcription factor. Further analysis of NTF-1 may lead to a better understanding of its potential role in modulating the expression of developmentally programmed genes.

\section{Results}

Purification, DNA-binding specificity, and transcriptional activity of NTF-1

Because the DNA-binding activity of NTF-1 on the $U b x$ promoter was detected in Drosophila embryos at certain stages of development, we attempted to purify this putative cell-type-specific factor from such extracts. Crude nuclear extracts were prepared from embryos and subjected to heparin-agarose and S-300 gel filtration chromatography. Fractions containing $U b x$ promoter-binding factors (determined by DNase I footprinting) were pooled, and the NTF-1 activity was purifed by three sequential cycles over a specific DNA affinity column containing multimers of an oligonucleotide derived from the corresponding sequence in the $U b x$ proximal promoter (Biggin and Tjian 1988). Analysis of the affinity-purified proteins by SDS-gel electrophoresis revealed a collection of three prominent polypeptides (140, 120 , and $83 \mathrm{kD} \mid$, as well as some minor species $(170,67$, and $54 \mathrm{kD}$ ); (Fig. 1A). Typically, $10 \mu \mathrm{g}$ of affinity-purified protein was obtained from 250 grams of embryos. We estimate that the three major polypeptides in the DNA affinity preparations have been purified at least 20,000fold. The same yield and pattern of polypeptides are also obtained when DNA affinity chromatography is carried out with a resin containing the NTF-1-binding sites derived from the $D d c$ promoter element $\mathrm{I}$, which is essential for neuronal expression (Bray et al. 1988). In some preparations, we used DNA affinity resins containing the $U b x$ - and $D d c$-binding sites consecutively, and the same three major polypeptide species were always isolated (data not shown). Our results suggest that these proteins recognize and bind to cis control elements common to both $U b x$ and $D d c$, either as a complex or as members of a family of DNA-binding proteins.

In addition to the $D d c$ gene, cis-acting regulatory sequences required for neuronal expression in the CNS have also been identified for the segmentation gene $f t z$ (Hiromi et al. 1985). Recent analysis of this $\mathrm{ftz}$ 'neurogenic' element has identified a DNA segment that can confer high levels of expression in the CNS (Y. Hiromi and C.S. Goodman, pers. comm.). Interestingly, this segment contains multiple stretches that show similarity to the $U b x$ and $D d c$ DNA sequences recognized by NTF-1. Therefore, we were prompted to compare the DNA-binding specificity of purified NTF-1, using endlabeled DNA probes derived from $U b x, D d c$, and $f t z$ by DNase I footprint analysis (Fig. 1C). As expected, binding of affinity-purified NTF-1 to a DNA fragment of $U b x$ containing proximal promoter sequences revealed a distinct DNase I footprint in the region of the promoter $(-103$ to -119$)$ that had been designated previously as FP4 (Biggin and Tjian 1988). DNase I protection analysis of the $D d c$ template confirmed that NTF-1 was responsible for binding specifically to a single site within the cis-control sequences, referred to as element I. In contrast, binding of NTF-1 to a DNA probe containing sequences from the previously defined neurogenic enhancer of $f t z$ identified four DNase I-protected regions, each containing a sequence that is homologous to the $U b x-$ and $D d c$-binding sites. These findings established that NTF-1 polypeptides can recognize and bind selectively to a number of homologous cis-control elements (Fig. 1C) necessary for expression in specific cells of the nervous system.

Reconstituted in vitro transcription reactions were performed to determine whether NTF-1 could act directly as a promoter-selective transcription factor by binding to its cognate recognition sequences. Transcriptionally active nuclear extracts were prepared from embryos and then selectively depleted of NTF-1, using DNA affinity resin bearing high-affinity NTF-1-binding sites. Extracts that lack detectable endogenous NTF-1 were first tested for transcription with $U b x$ templates, which either lack the NTF-1-binding site (but retain GAGA and zeste sites) $(\Delta-94$, control) or contain most of the proximal promoter binding sites, including the NTF-1 site $(\Delta-132$, test template) (see Fig. 6$)$. Both the 
A

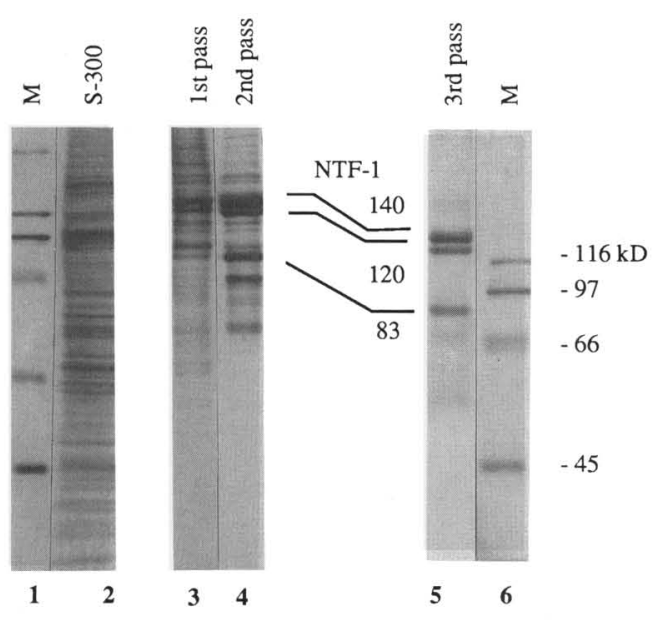

C

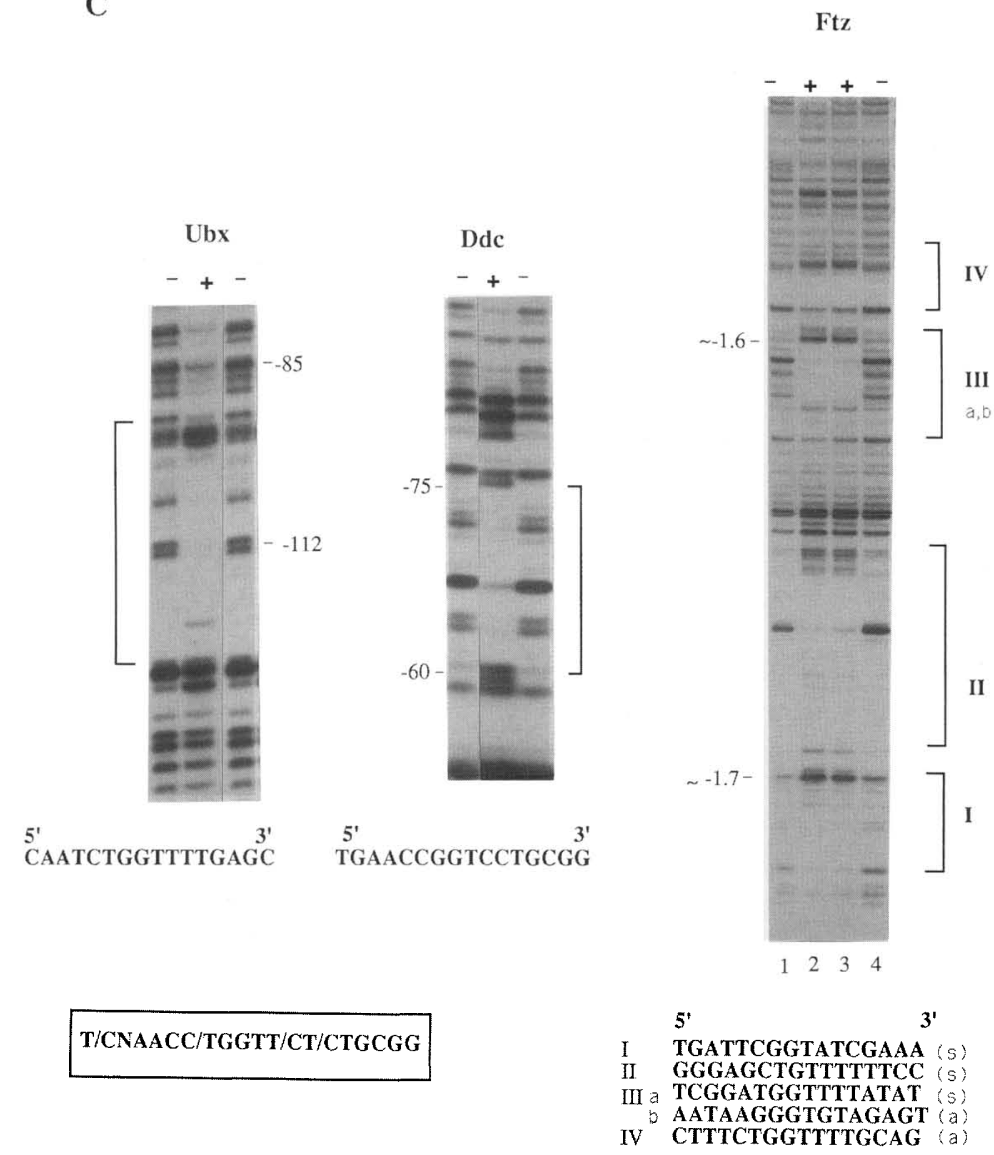

B
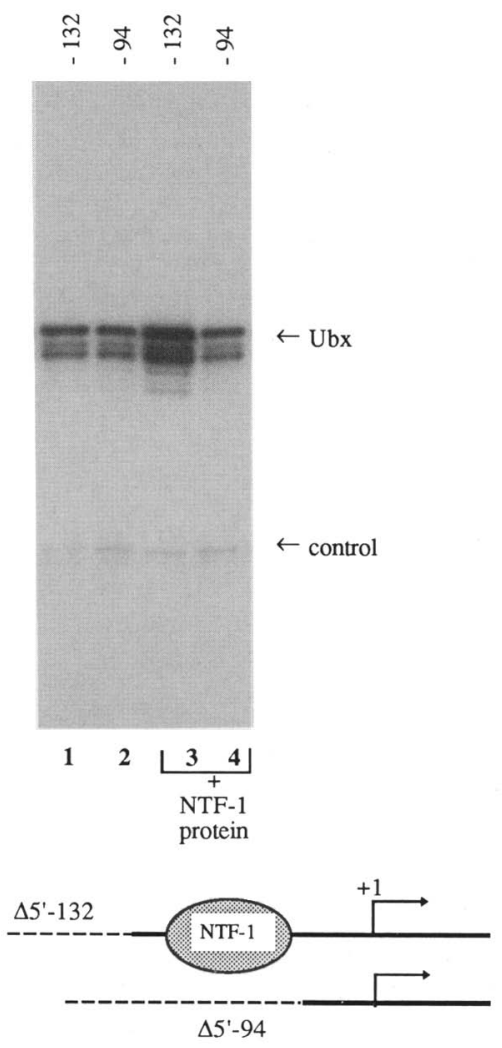

Figure 1. Purification and identification of NTF-1 from embryos and in vitro transcriptional activation. (A) Analysis of protein fractions from different stages of the NTF-1 purification by $8 \%$ SDS-polyacrylamide gel electrophoresis and silver staining. (Lanes 1 and 6) Molecular weight markers; (lane S-300) $6 \mu \mathrm{g}$ of protein, 0.1 footprinting units $(U b x)$; (1st pass) firstpass affinity eluate, $1.0 \mu \mathrm{g}$ of protein, 2 footprinting units $(U b x)$; (2nd pass) second-pass affinity eluate, 1.0 $\mu \mathrm{g}$ of protein, 50 footprinting units $(U b x)$; (3rd pass) third-pass affinity fraction, $0.5 \mu \mathrm{g}$ of protein, 150 footprinting units $(U b x)$. The sizes (in $\mathrm{kD}$ ) of the major species of NTF-1 purified are indicated. $(B)$ (Bottom) schematic diagram of the $U b x$ templates used for the in vitro transcription analyses, which represents the position of the NTF-1-binding site (shaded oval) relative to the in vivo $U b x$ start site (arrows). (Top) S1 nuclease analysis of transcripts produced in vitro either from the $U b \times 5^{\prime}$ deletion $\Delta-132$ (pUbX $\Delta 5^{\prime}$-132) containing the NTF-1-binding site (lanes 1 and 3) or the $\Delta-94$ template (pUbx $\Delta 5^{\prime}-94$ ) lacking the binding site (lanes 2 and 4). In each case, reactions contained $225 \mathrm{ng}$ of $U b x$ template and $25 \mathrm{ng}$

of $A d h$ control template. Reactions either lacked (lanes 1 and 2) or contained (lanes 3 and 4) 150 ng of exogenous NTF-1 purified from embryos (third-pass affinity fraction). In addition, all reactions contained $120 \mu \mathrm{g}$ of 8 - to 12 -hr nuclear extract that had been depleted of NTF-1 with affinity resin (see Experimental procedures). Densitometry of these autoradiograms indicates a fourfold stimulation of transcription by NTF-1. This is most likely a minimum estimate because the level of activation depends on the extent of depletion of NTF-1; this is confirmed by the experiment in Fig. 5C, where a different depleted extract was used. (C) DNase I footprint analysis of purified NTF-1 on the $U b x, D d c$, and $f t z$ promoters. The $U b x$ probe consisted of a 568 -bp HindIII-EcoRI promoter fragment that was $5^{\prime}$-labeled at the HindIII site of pHIII $\Delta 5^{\prime}-201$ (equivalent to -206 ). The $D d c$ probe was an NcoI-EcoRI fragment 5'-labeled at the NcoI site, and the $f t z$ probe was an $X b a I-P v u I I$ fragment 5 '-labeled at the $X b a I$ site (see Experimental procedures). Footprint reactions either contained $(+\mid$ or lacked $|-|$ NTF-1 purified from embryos. Footprint reactions marked as + for the $U b x$ and $D d c$ promoters each contained $5 \mathrm{ng}$ of affinity-purified embryo NTF-1. Footprinting reactions on the ftz probe contained either $50 \mathrm{ng}$ (lane 2) or $20 \mathrm{ng}$ (lane

(Legend continued on following page.) 
Dynlacht et al.

control and test templates were transcribed by the embryo extracts depleted of NTF-I with equal but low efficiency (Fig. 1B), which is consistent with our previous observation that the zeste and GAGA proteins remaining in the extract are sufficient to confer a modest basal level of transcription. However, when purified NTF-1 is added to the depleted nuclear extract, transcription of the $\Delta-132$ template containing a strong NTF-1-binding site is activated significantly (fourfold) relative to the control $\Delta-94$ template, which lacks an NTF-1-binding site. Experiments carried out with the $D d c$ template have produced similar results (data not shown). These experiments establish that purified NTF-1 can act as a binding site-dependent transcription factor in vitro.

\section{Molecular cloning and characterization of an NTF-1 $c D N A$}

The ability of NTF-1 to bind several cis-control elements associated with cell-type-specific expression in Drosophila, coupled with its activity as a transcription factor in vitro, suggested that NTF-1 may also be an important regulatory protein in vivo, functioning in a temporally controlled and spatially restricted manner during development. A valuable clue in understanding the potential role of NTF-1 during embryogenesis would be to determine whether its expression is developmentally staged and cell-type specific. In addition, a more complete understanding of the structure and function of NTF-1 and the molecular basis for its transcriptional activity would require a thorough genetic and biochemical investigation. Therefore, we set out to isolate cDNA clones that encode NTF-1 as a direct approach to address some of these issues. Thus, we generated various cyanogen bromide $(\mathrm{CNBr})$-cleaved peptides from the most highly purified (third-pass DNA affinity) NTF-1 preparations and determined partial amino acid sequence after separating the peptides by reverse-phase high-performance liquid chromatography (HPLC). A 45-nucleotide synthetic oligomer corresponding to the deduced coding sequence of PEP2 (see Experimental procedures) was selected as a specific probe for screening a Drosophila embryonic cDNA library. Two independent cDNA clones were isolated from 500,000 $\lambda$ gt11 phage plaques. The DNA sequence of the longest NTF-1 cDNA clone 13.2 $\mathrm{kb}$ ) was determined, and the predicted amino acid sequence (Fig. 2) reveals an extended ORF of $2.5 \mathrm{~kb}$; a search through various data bases (NBRF, EMBL) has revealed no striking homology to proteins catalogued in these data bases. However, a region of NTF-1, $\sim 300$ residues from the carboxyl terminus, does appear to bear weak homology to the proteins myogenin (Wright et al. 1989) and MyoD (Davis et al. 1987) and to the Droso-

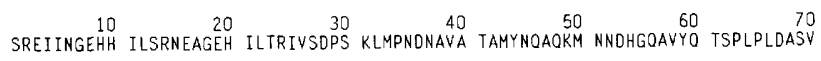

$$
\begin{aligned}
& \begin{array}{lllllll}
80 & 90 & 100 & 110 & 120 & 130 & 140
\end{array} \\
& \text { LHYSGGNDSN YIKTEADIYE DHKKHAAAAA AAAGGGSIIY TTSOPNGYNY KQLPHLTYPO KLDPDLYOAD }
\end{aligned}
$$

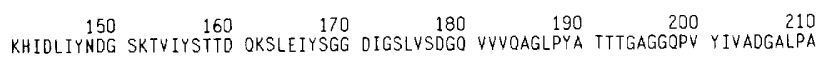

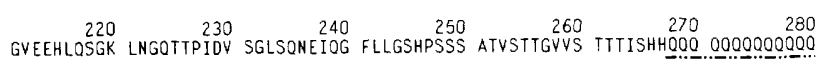

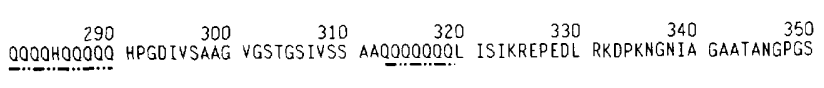

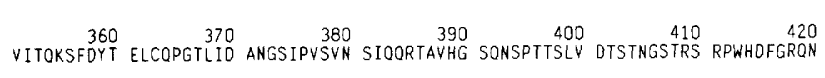

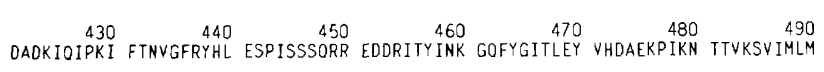

$$
\begin{aligned}
& 500 \text { FREEKSPEDE IKAWOFWHSR OHSVKORILD ADTKNSVGLV GCIEEVSHNA IAVYWNPLES SAKINIAYOC }
\end{aligned}
$$

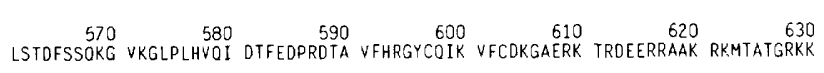

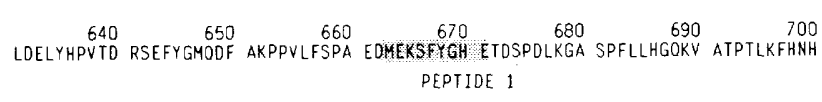

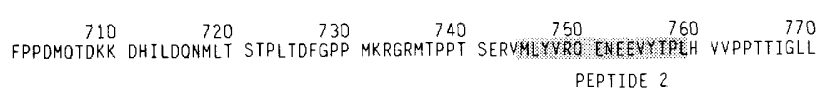

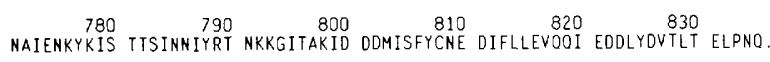

Figure 2. Amino acid sequence of a Drosophila NTF-1 partial cDNA. The two CNBr peptides that were sequenced are enclosed in shaded boxes. Polyglutamine stretches in NTF-1 are indicated by a broken line.

phila regulatory proteins daughterless (Caudy et al. 1988), achaete-scute (Villares and Cabrera 1987), and twist (Thisse et al. 1988) in a region predicted to have a helix-loop-helix structure (Murre et al. 1989), which is thought to be involved in DNA binding and dimerization. The 835-amino-acid-coding region of NTF-1 contains the PEP2 sequences, as well as another shorter amino acid sequence of 9 residues corresponding to PEP1. This ORF would theoretically yield a protein of $\sim 92 \mathrm{kD}$, suggesting that we have not isolated a cDNA encoding the full-length ORF. Instead, we have most likely isolated a partial cDNA clone corresponding to one of the two higher molecular weight proteins (140 or $120 \mathrm{kD}$ ), and the full-length cDNA probably extends beyond the $5^{\prime}$ end of the cDNA we isolated. This possibility appears likely because the ORF begins precisely at the $5^{\prime}$ end of the CDNA we isolated.

Northern blot analysis using an NTF-1 cDNA probe detected two major mRNA species of $\sim 10.6$ and $7.4 \mathrm{~kb}$ (Fig. 3A). These results confirm that even our longest clone does not represent a full-length CDNA, and the

3) of affinity-purified NTF-1 protein. A footprint was detectable on elements I and II with $10 \mathrm{ng}$ of NTF-1, and elements III and IV are visibly protected with $3 \mathrm{ng}$ (B.D. Dynlacht, unpubl.). The element IV footprint is more clearly seen on the opposite strand (data not shown). Distances to binding sites in the $f t z$ promoter are approximate, as the entire upstream region has not been sequenced completely. Listed below each panel is the DNA sequence corresponding to the NTF-1-binding site in each promoter. (s and a) Sense and anti-sense strands, respectively. The NTF-1 consensus sequence is enclosed in a box. 

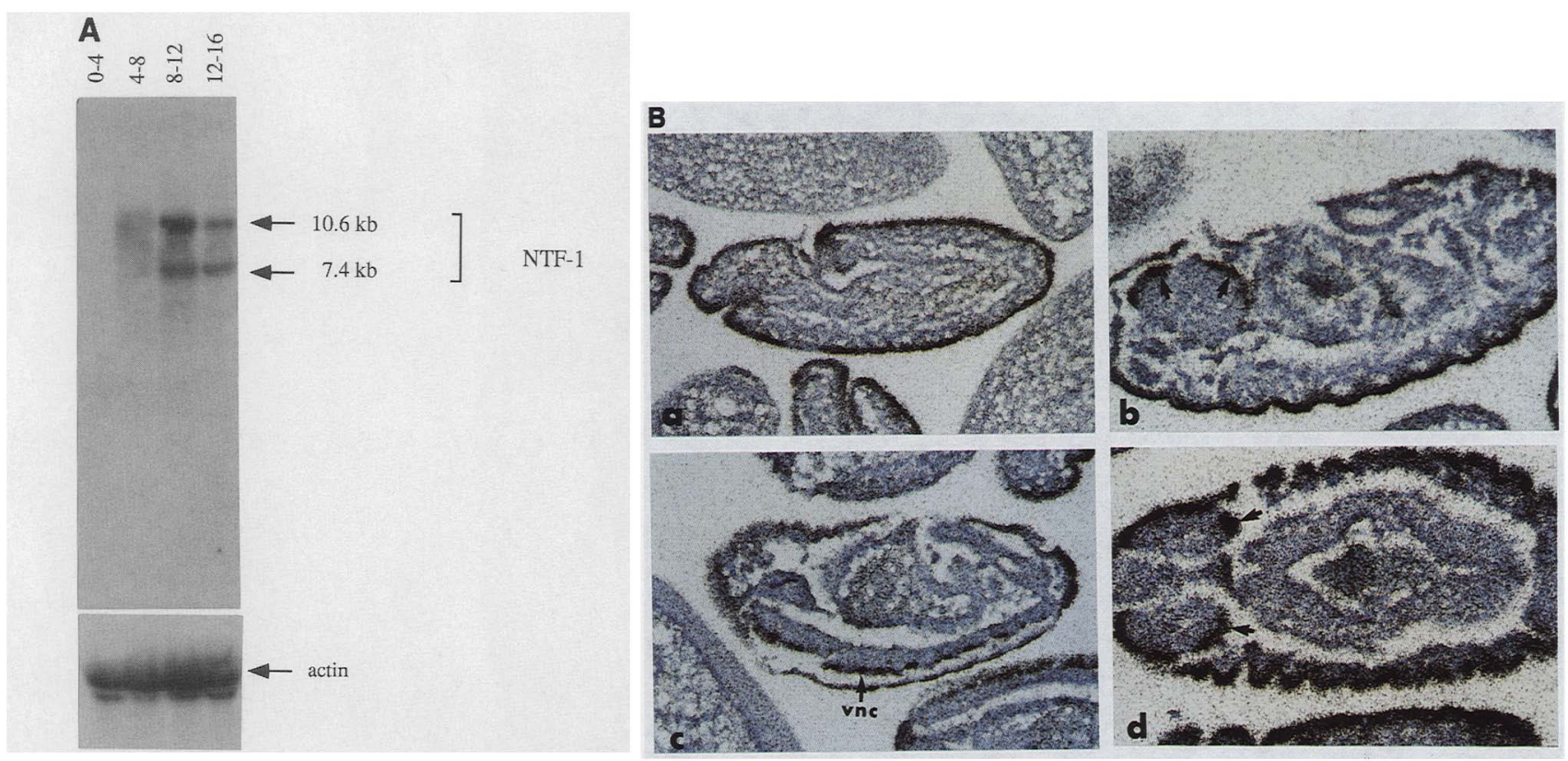

Figure 3. Temporally and spatially regulated expression of NTF-1 mRNA. (A) Northern blot of total RNA from various stages of Drosophila embryogenesis. The age of the embryos (hours postfertilization) from which the RNA was obtained is indicated above each lane. The blot was first probed with a 3.4-kb NotI-SalI fragment of pBS-NTF-1-12 and subsequently with an actin probe /see Experimental procedures). Molecular mass markers (data not shown) ranged in size from 0.24 to $9.5 \mathrm{~kb}$. (B) In situ hybridizations with ${ }^{35}$ S-labeled probe to sectioned embryos at several stages of development. The NTF-1 message is visualized as silver grains. All stages are described according to Campos-Ortega and Hartenstein (1985). Embryos are oriented with anterior left, dorsal up. Control embryos hybridized with the opposite-sense strand did not show a detectable signal above background (data not shown). (a) Parasagittal section from stage-10/11 (4-7 hr) embryo, showing uniform NTF-1 expression in cells of the epidermis. (b) Parasagittal section from stage-12 (7-9 hr) embryo showing NTF-1 expression in dorsal and posterior regions of the cortex of the developing supraesophageal ganglion (arrows). (c) Late stage-14/15 (11-13 hr) embryo, parasagittal section, showing diminished expression in cells of the epidermis and expression in the ventral side of the ventral nerve cord (vnc, arrow). (d) Horizontal section through a stage-13 (9-10 hr) embryo, focusing on expression in the supraesophageal ganglion (arrows). (C) In situ hybridizations with digoxigenin-containing NTF-1 probe to whole-mount embryos. Embryos are oriented as in B. NTF-1 is expressed at various stages of development in large cells that we believe to be neuroblasts. (a) Stage-13 embryo, which focuses on the middle of the ventral nerve cord and shows what are probably abdominal median neuroblasts (indicated by arrow). Also shown is a segmentally repeated pattern in the epidermis (discussed in the text). (b) Detail of $a$, focusing on median neuroblasts. (c) The same embryo as in $b$ but through a different focal plane. A complex pattern of large, bilaterally symmetric cells (arrow) is indicated. (d) Slightly earlier embryo than in $a$, showing expression in large cells (arrows) on either side of the ventral nerve cord. (e) Expression in the spiracles (arrow).

length of these messages suggests that the mRNA species possess long stretches of noncoding sequence; moreover, we do not know the relationships between the mRNA species detected here and the purified NTF-1 polypeptides. Inspection of the abundance of NTF-1 mRNAs in total RNA preparations isolated from Drosophila embryos at different stages during development reveals that NTF-1 is indeed expressed in a temporally regulated fashion. There is no detectable mRNA in 0- to 4-hr embryos, which is consistent with the absence of NTF-1-binding activity in 0 - to 4 -hr embryo extracts (Biggin and Tjian 1988). Low levels of NTF-1 are first detected in 4- to 8-hr embryos, maximal expression occurs in 8- to 12-hr embryos, and somewhat reduced levels are visible in 12- to $16-\mathrm{hr}$ embryos. These results suggest that there may be at least two distinct species of mRNA, perhaps generated by alternative splicing, corresponding to NTF-1, and that both are expressed in a developmental stage-specific manner.
A key issue is whether NTF-1 is also expressed in a cell-type-specific fashion in the embryo. To address this question, we performed in situ hybridization experiments with probes derived from the cDNA clone (Fig. $3 B, C)$. Because we have not yet defined probes specific to the two RNA species seen in the Northern blots, the in situ localization represents the sum of the regions of expression of both transcripts. In agreement with our Northern blot analysis, no expression of NTF-1 was detected in 0 - to 4-hr-old embryos by in situ hybridization. However, by 5- to 5.5-hr, expression of NTF-1 was detected throughout the ectoderm by hybridization with a radioactively labeled probe (Fig. 3B, a). Later embryos (9to 12-hr) show expression of NTF-1 in the ventral nerve cord and in the brain (Fig. 3B, b-d). It is not possible to determine the exact stage at which ventral nerve cord expression commences, because this technique does not permit resolution between the epidermis and the abutting nerve cord before $\sim 9 \mathrm{hr}$. After $12 \mathrm{hr}$, the embryos 

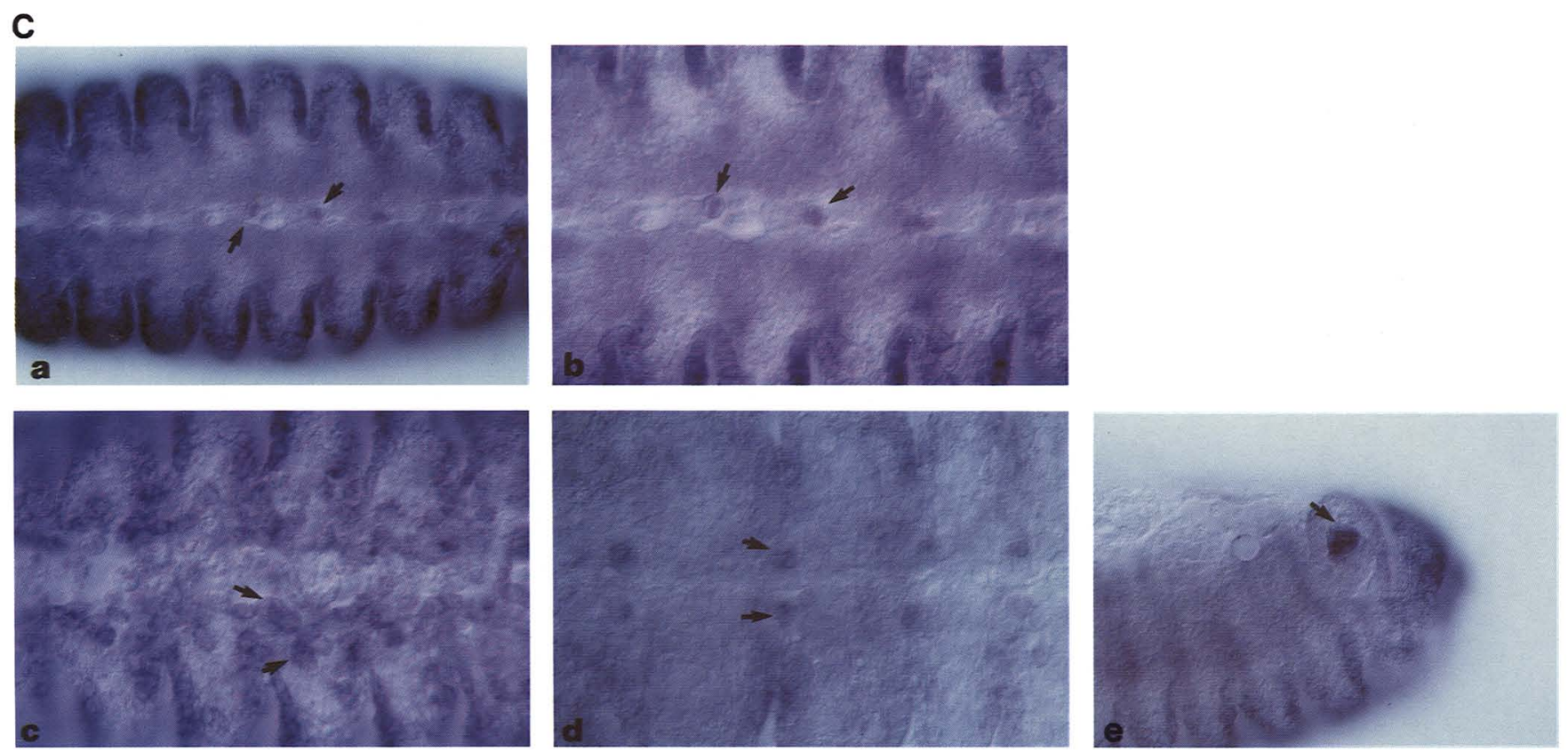

display lower levels of NTF-1 in the epidermis (data not shown).

We have also attempted to localize NTF-1 expression to specific cell types by in situ hybridization with a digoxigenin-labeled probe. This method has allowed us to verify NTF-1 expression in the epidermis, and it reveals a segmentally repeated pattern (Fig. 3C, a). Here, anterior segments express NTF-1 in both anterior and posterior regions of the segment, whereas posterior segments only express NTF-1 in posterior regions of the segment; the significance of this pattern of expression is currently unknown. In addition, large cells, possibly neuroblasts (Fig. 3C, b-d), and spiracles (Fig. 3C, e) express NTF-1. These results indicate that NTF-1 is indeed expressed in a limited set of cells during mid-embryogenesis.

Finally, we localized the gene encoding NTF- 1 to position 54F1-2 of polytene chromosomes (data not shown); there are no characterized developmental mutations that are known to map to this region.

\section{Expression and biochemical characterization of NTF-1}

Because NTF-1 purified from embryos consists of at least three polypeptides of different molecular weights, it was important to ascertain whether the cDNA clone we isolated encodes a functionally active product endowed with the same biochemical properties as the collection of proteins isolated from Drosophila. In particular, it was of interest to test whether the polypeptide species, which is encoded by the cDNA, could function as a sequence-specific transcription factor. Therefore, we used vaccinia virus as a vector to express a portion of the NTF-1 cDNA in mammalian cells. NTF- 1 made after infection of HeLa cells with the recombinant virus was subsequently isolated by DNA affinity chromatography, and purified proteins were analyzed by SDS-gel electrophoresis. A polypeptide of $\sim 80 \mathrm{kD}$ was the only product detectable in these affinity-purified preparations (Fig. 4). In contrast, no protein was purified on the NTF-1-specific DNA affinity column from cells infected with a nonrecombinant (control) virus.

Next, we tested the ability of the vaccinia virus-expressed NTF-1 proteins to bind cis-control elements in the proximal promoters of $U b x$ and $D d c$. DNase I protection assays reveal that the vaccinia virus-expressed $80-\mathrm{kD}$ protein recognizes the same binding sites in the promoters of $U b \mathrm{x}$ and $D d c$ (element I) as native Drosophila embryo NTF-1 (Fig. 5A,B). Side-by-side comparison of the DNase I footprint protection patterns indicates that the binding specificity and affinity of the $80-\mathrm{kD}$ protein alone is indistinguishable from the collection of three proteins isolated from Drosophila. These DNA-binding studies confirm that the NTF-1 cDNA we isolated encodes at least one of the components that corresponds to Drosophila NTF-1.

\section{Vaccinia virus-expressed NTF-1 activates Ubx transcription in vitro}

We have shown that the native Drosophila NTF-1 protein not only functions as a DNA-binding protein but also as a binding site-dependent transcriptional activator. Therefore, we were particularly interested in characterizing the activation properties of the $80-\mathrm{kD}$ NTF-1 species expressed in HeLa cells. As before, the transcriptional properties of NTF-1 were tested using an embryonic extract that had been depleted of endogenous NTF-1 (Fig. 5C). The addition of purified vaccinia virusexpressed NTF-1 to this depleted embryonic extract strongly activates $U b x$ transcription in vitro from a template containing the NTF-1-binding site $(-132)$ but not from a control template lacking the NTF-1 recognition sequence $(-94)$. The level of activation by the $80-\mathrm{kD}$ species was comparable to the stimulation of 


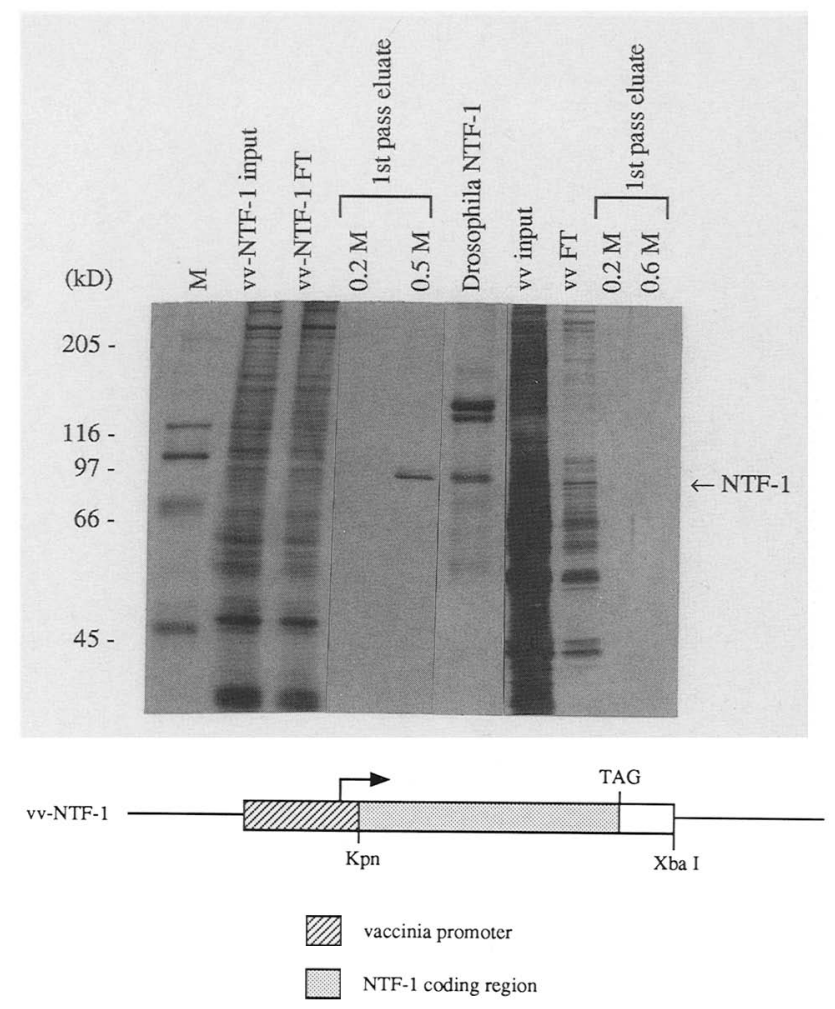

Figure 4. Purification of NTF-1 expressed in HeLa cells. (Bottom) Schematic representation of the vaccinia vector, vvNTF-1, used to express the NTF-1 cDNA in HeLa cells. The hatched area indicates the vaccinia promoter, the arrow indicates the direction of transcription, and the stippled area indicates the NTF-1 ORF. The unshaded area represents the $3^{\prime}$ untranslated region of the NTF-1 cDNA. (Top) Silver-stained $8 \%$ SDS-polyacrylamide gel, demonstrating the purification of NTF-1 from crude nuclear extracts. (Lane $M$ ) Molecular weight markers whose sizes are listed (left). (Lane $v V-N T F-1$ input) The crude nuclear extract from HeLa cells infected with recombinant vaccinia virus containing the partial NTF-1 ORF (see bottom); (lane vv input) a crude nuclear extract from HeLa cells infected with the New York City Board of Health (NYCBH) strain of vaccinia virus lacking the NTF-1 insert. (Lanes $V V$ NTF-1 FT and $v V$ FT) Fractions flowing through first-pass affinity columns loaded with nuclear extracts from vv-NTF-1 input and $\mathrm{vv}$ input, respectively. (Lanes 1 st pass eluate) Proteins purified from first-pass affinity columns and eluting at the $\mathrm{KCl}$ concentration listed above each lane; proteins eluted from the column loaded with vv-NTF-1 input are in the middle, and proteins eluted from the vv input control column are shown (right). For comparison, Drosophila embryo NTF-1 (third-pass affinity-purified; see Fig. 1 ) is also shown. The mobility of NTF-1 purified from HeLa cells is indicated (right).

transcription observed for native NTF-1 purified from Drosophila embryos. These results establish conclusively that the isolated cDNA encodes part of a promoter-selective transcription factor with the DNAbinding specificity of NTF-1.

\section{Discussion}

Several different approaches have been taken in an effort to understand how DNA-binding regulatory proteins interact with one another to generate complex and diverse patterns of gene expression during Drosophila development. For example, many components of this developmental regulation have been identified genetically (for review, see Ingham 1988), whereas others have been defined by promoter deletion analysis (Hiromi et al. 1985; Bienz et al. 1988). Yet another way to study this question has been to fractionate embryonic nuclear extracts with the hope of biochemically identifying the activators of transcription in vitro (Biggin and Tjian 1988; Biggin et al. 1988; Perkins et al. 1988; Soeller et al. 1988), and this approach may uncover regulators not identified in a genetic screen. We have taken the latter approach and have continued to characterize transcriptional activators of $U b x$, a gene whose temporal and spatial patterns of expression vary greatly during embryogenesis. To this end, we have identified and begun to analyze a novel, sequence-specific DNA-binding transcription factor, NTF-1, able to stimulate transcription from the $U b x$ promoter in vitro. Although earlier reports had provided evidence for an activity present in crude embryo extracts, but not in $\mathrm{Kc}$ tissue culture cells, capable of binding sequences upstream of the $U b x$ and Ddc start sites (Biggin and Tjian 1988; Bray et al. 1988), this DNA-binding protein had not been identified in genetic screens for regulators of $U b x$. It was shown, however, that the cis element (element II of the Ddc promoter, to which NTF-1 binds, was essential for neuronal expression of $D d c$ (Scholnick et al. 1986).

We have purified NTF-1 and find that multiple polypeptides copurify with this activity. This suggests either that the purified proteins are able to bind to sequencespecific DNA affinity columns as a multimeric complex or that the polypeptides are related by an ability to bind similar DNA sequences. The polypeptides could, for example, be related by alternative splicing or by differential post-translational modification; alternatively, they could be products of multiple genes. Indeed, there is a precedent for families of transcription factors, such as the CTF/NF-1 family of DNA-binding proteins, which are related, in part, by alternative splicing (Santoro et al. 1988), and the AP-1 family of factors, which are encoded by different, but related, genes (Bohmann et al. 1988). Polyclonal antibodies generated against purified NTF-1 and additional cDNA clones should permit a more thorough characterization of the multiple forms of this protein. If multiple species of NTF-1 do exist, it raises the interesting possibility that they could be localized to different embryonic tissues.

We cloned a cDNA corresponding to NTF-1 from a Drosophila embryo library. NTF-1 does not appear to contain a homeo box or zinc-finger DNA-binding motif (McGinnis et al. 1984; Scott and Weiner 1984; Berg 1986; Kadonaga et al. 1987), although there is some detectable homology to the helix-loop-helix structure in the proteins MyoD and myogenin. In addition, in the sequence thus far obtained, we failed to detect any highly acidic regions characteristic of the transcriptional activation domains of the yeast activators GCN4 and GAL4 or of the viral VP16 protein (Hope and Struhl 1986; Gill and Ptashne 1987; Ma and Ptashne 1987; Treizenberg et 


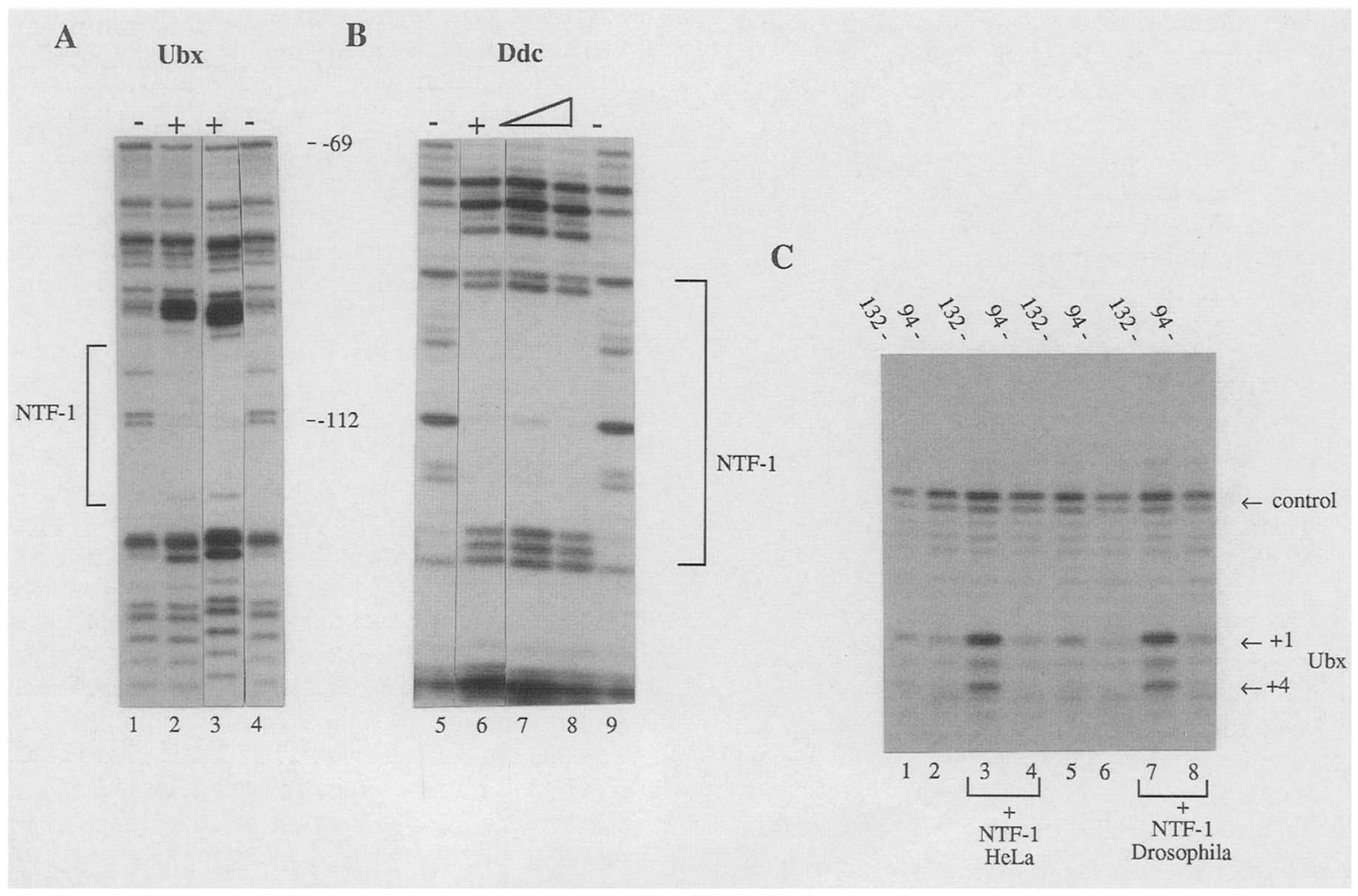

Figure 5. Biochemical analysis of NTF-1 expressed in, and purified from, HeLa cells. (-) Control pattern of digestion in the absence of added NTF-1 protein. ( + | Footprint patterns obtained when either Drosophila embryo or HeLa cell-expressed NTF-1 is included in the reaction. (A) DNase I footprint analysis of purified NTF-1 on the $U b x$ promoter using the probe described in Fig. 1. (Lane 2) Five nanograms of embryo protein; (lane 3) $2.5 \mathrm{ng}$ of HeLa cell-expressed protein. (B) DNase I footprint analysis of purified NTF-1 on the $D d c$ promoter using the probe described in Fig. 1. (Lane 6) Five nanograms of embryo protein; (lane 7) $2.5 \mathrm{ng}$ of HeLa cell-expressed protein; (lane 8) $12.5 \mathrm{ng}$ of HeLa cell-expressed protein. (C) S1 nuclease analysis of in vitro transcription reactions directed by the $U b x$ deletion and $A d h$ control templates described in Fig. 1. All reactions included $125 \mathrm{ng}$ of $U b \mathrm{x}$ template, $125 \mathrm{ng}$ of $A d h$ template, and $120 \mu \mathrm{g}$ of NTF-1-depleted 8- to 12-hr nuclear extract. In addition, reactions contained either no exogenous NTF-1 (lanes 1,2, 5, and 6), HeLa cell-expressed, affinity-purified NTF-1 (160 ng, lanes 3 and 4), or third-pass affinity-purified embryo NTF-1 (150 ng, lanes 7 and 8). Densitometry of these autoradiograms reveals that the level of NTF-1 transcriptional stimulation is approximately sixfold.

al. 1988). We noted, however, that NTF-1 contains several glutamine-rich regions found in a number of homeo-box-containing genes, such as Antennapedia (Schneuwly et al. 1986) and cut (Blochlinger et al. 1988). Although the function of this repeat motif remains unclear, it is interesting to note that the mammalian transcriptional activator $\mathrm{Spl}$ contains glutamine-rich stretches that map to transcriptional activation domains of this protein (Courey and Tjian 1988); moreover, a glutamine-rich region of the Antennapedia gene product can also function as an activation domain (A.J. Courey et al., in press.).

We have also expressed NTF-1 in HeLa cells using a vaccinia virus expression vector, and we find that NTF-1 purified from such cells possesses the same DNAbinding and transcriptional activation properties in the assays used in this study as the collection of polypeptides purified from Drosophila embryos, although it remains to be determined whether all of the proteins that copurify with the NTF-1 activity, or only a subset, are transcription factors capable of binding to NTF-1 sites.

In contrast to two previously characterized in vitro ac- tivators of $U b \mathrm{x}$, the zeste and GAGA proteins, which seem to be expressed in most cells of the embryo (Pirrotta et al. 1988; W. Soeller, pers. comm.), we have shown that expression of NTF-1 is temporally and spatially restricted. NTF-1 expression is first detected about $5 \mathrm{hr}$ after fertilization during the germ-band-extended stage of development, and expression of the NTF-1 message appears to be limited to the epidermis and a subset of cells of the CNS. Our data indicate that NTF-1 is expressed in a segmentally repeated pattern in the epidermis, in large cells that appear to be neuroblasts, and in the cortex of the developing embryonic brain. Determination of the exact identity of these cells will require double-labeling experiments with antibodies to a known, cell-type-specific protein; a collection of neuron-specific marker proteins has been documented (Patel et al. 1989).

In addition to previously reported data showing that this protein binds element I of the $D d c$ promoter (Bray et al. 1988), the Ubx proximal promoter, and the engrailed promoter (W. Soeller, pers. comm.), we have provided evidence that NTF-1 binds to multiple sites within the 
$f t z$ neurogenic element. However, at present, the role of NTF-1 in Drosophila development remains unknown. Interestingly, the temporal profile of NTF-1 expression overlaps significantly with that of $U b x$ in the CNS. Therefore it is tempting to speculate that NTF-1 is involved in specifying expression of genes like $U b x, D d c$, and $f t z$ in the CNS. However, it seems evident that NTF-1 cannot be the primary determinant of temporal or cell-type specificity for all of these genes because $D d c$ and $f t z$ expression are not coincident with each other or with the peak of NTF-1 expression. Instead, it seems more likely that NTF-1 may serve as one of several sequence-specific transcription factors that can influence expression of these developmentally programmed genes. Given the precedent observed in other transcription systems in which a single DNA recognition site can interact with multiple distinct factors, it is reasonable to anticipate that additional regulatory proteins may be involved in specifying the patterns of $U b x, D d c$, and $f t z$ expression. We hypothesize that the exact pattern of expression of each of these genes is specified by interactions between unique combinations of transcriptional regulators. For example, $D d c$, but not $U b x$, may be expressed in the embryonic brain as a consequence of the interactions between NTF-1 and other, more distal factors that bind to the $D d c$ promoter but not to $U b x$ upstream elements. The evidence for such a combinatorial model is most suggestive for the regulation of $D d c$ expression. For example, it has been demonstrated that deletion of Ddc element I, to which NTF-1 binds, results in loss of CNS expression but only slight decreases in hypodermal expression (Scholnick et al. 1986). Moreover, element I alone is not sufficient to confer wild-type expression of Ddc in the CNS (Beall and Hirsh 1987; Bray et al. 1988). This suggested that at least two upstream regions of $D d c$ were essential for expression of this gene in the CNS and provides support for the requirement of interactions between distal and more proximal factors (such as NTF-1) in the regulation of $D d c$ expression. Similarly, $U b x$ expression may, in part, result from specific interactions between zeste, GAGA, NTF-1, homeo domain proteins, and other genetically defined regulators of $U b x$ (see Fig. 6).

Availability of the NTF-1 cDNA will allow us to study, on a biochemical level, the interactions between NTF- 1 and other regulators of $U b x$ expression in vitro, and knowledge of the chromosomal location of NTF-1 will allow us to undertake a genetic analysis to uncover mutants in the NTF-1 locus and to study the developmental effects of such mutations. Moreover, a mutational analysis of NTF-1 sites in the $U b x$ promoter and $f t z$ enhancer will be important in determining whether these sites are functionally important for directing wildtype levels and correct spatial patterns of expression of these genes in vivo. Furthermore, double-labeling experiments using antibodies against NTF- 1 and $U b x$ and $f t z$ gene products will determine the extent to which the patterns of expression of these genes overlap.

\section{Experimental procedures}

Purification of NTF-1 and peptide sequencing

Nuclear extracts from 0- to 12 -hr embryos (250 grams) were fractionated by heparin-agarose and Sephacryl S-300 column chromatography essentially as described (Perkins et al. 1988). S-300 column fractions containing NTF-1 footprinting activity were pooled $(\sim 300 \mathrm{ml}, 1.2 \mathrm{mg} / \mathrm{ml}$ of protein $)$, supplemented with lauryldimethylamine oxide (LDAO) $(0.1 \%)$ and poly[d(I-C)] $(3.9 \mathrm{mg})$, incubated on ice for $10 \mathrm{~min}$, and centrifuged at $9000 \mathrm{rpm}$ for $10 \mathrm{~min}$ in a Sorvall SS-34 rotor. Then the supernatant protein was applied to a 1-ml DNA affinity column, as described previously (Kadonaga and Tjian 1986). The affinity resin contained either the NTF-1-binding site in the Ubx promoter, in which case the complementary oligonucleotides used were 5'-GATCT AACGCTCAAA ACCAG ATTGT TT-3' and 5'GATCA AACAATCTGG TTTTG AGCGT TA-3' or the NTF-1-binding site in the Ddc promoter, in which case the sequences used were 5'-TCGAG CAGGA CCGGT TCAA-3' and 5'-TCGATTGAAC CGGTC CTGC-3'. The column was equilibrated first with $0.1 \mathrm{M} \mathrm{HEMG}[25 \mathrm{mM}$ HEPES/ $\mathrm{KOH}$ (pH 7.6), 0.1 mM EDTA, $12.5 \mathrm{~mm} \mathrm{MgCl}_{2}, 10 \%$ glycerol, $1 \mathrm{~mm} \mathrm{DTT}$, and 0.1 $\mathrm{M} \mathrm{KCl}$ ] containing $0.1 \% \mathrm{LDAO}$. The column was washed with 8 volumes of $0.1 \mathrm{M}$ HEMG and 3 volumes of $0.2 \mathrm{M}$ HEMG. Then the protein was eluted from the column with steps of HEMG containing $0.3 \mathrm{M}(2 \mathrm{ml})$ and $1.0 \mathrm{M} \mathrm{KCl}(4 \mathrm{ml})$. The $1.0 \mathrm{M}$ step fractions, containing the bulk of NTF-1 footprinting activity, were pooled (NTF-1 typically eluted between 0.3 and $0.5 \mathrm{M}$ $\mathrm{KCl}$, diluted to $0.1 \mathrm{M} \mathrm{HEMG}$, mixed with poly[d(I-C)] to a final concentration of $1.6 \mu \mathrm{g} / \mathrm{ml}$, as described above, and loaded onto a second-pass affinity column. The column was washed and eluted as above, active fractions were pooled again and diluted to $0.1 \mathrm{M} \mathrm{HEMG}$, and poly[d(I-C)] was added to a final concentration of $0.8 \mu \mathrm{g} / \mathrm{ml}$, as described above. This protein was loaded onto a third-pass affinity column, which was washed and eluted as described above. Aliquots of protein fractions were TCA-precipitated, washed with acetone, and resuspended in sample buffer prior to SDS-polyacrylamide electrophoresis. Final yields of purified protein were estimated by silver staining.

$\mathrm{CNBr}$ peptides were generated, resolved, and sequenced as described (Williams et al. 1988), except that $15 \mu \mathrm{g}$ of protein was proteolyzed without prior modification.

\section{In vitro transcription and DNase I footprinting}

Adh control and $U b x$ deletion templates for in vitro transcription have been described previously (Biggin and Tjian 1988). 5'-

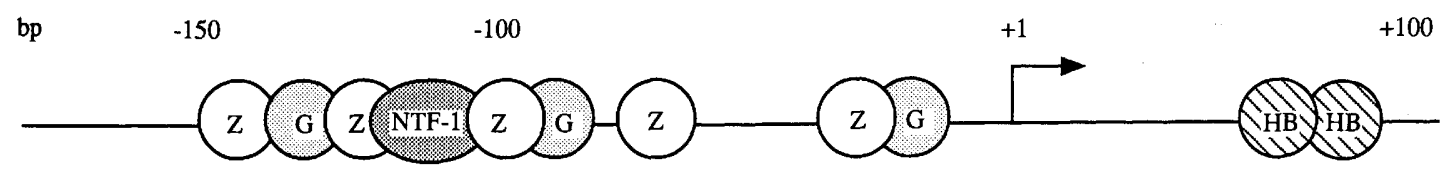

Figure 6. A summary of transcriptional regulatory proteins that bind to cis elements of the Ubx proximal promoter region. (Z) zeste; (G) GAGA protein; (HB) homeo domain proteins; the binding of these proteins to this promoter has been described (Beachy et al. 1988; Biggin and Tijan 1988). (Top) Numbers represent distances (in bp) relative to the transcription start site (denoted by arrow). 
Labeled single-stranded DNA probes used for S1 nuclease analysis of $U b x$ transcripts included a strand-separated DNA probe from a 306-bp MluI-HindIII fragment of pUbx HIII $\Delta 5^{\prime}-201$ las described in Biggin and Tjian 1988); (Fig. 1) or an oligonucleotide hybridizing to $U b x$ sequences +42 to -22 (Fig. 5). Transcription reactions were carried out as described by Biggin et al. (1988), except that the reactions contained 8- to 12 -hr nuclear extracts that had been depleted of NTF-1 as follows. Four hundred microliters of this nuclear extract was mixed for 30 min at $4^{\circ} \mathrm{C}$ with $D d c$ affinity resin $(200 \mu$ l packed volume), which had been pre-equilibrated with $0.1 \mathrm{M}$ HEMG. The suspension was centrifuged at $15,000 \mathrm{~g}$, and the resulting supernatant was subjected to a second round of depletion. The depleted extract was used directly or stored at $-70^{\circ} \mathrm{C}$.

DNase I footprint reactions $(50 \mu l)$ were carried out essentially as described (Heberlein et al. 1985; Jones et al. 1985). No competitor was added to the reactions, which contained $\sim 3$ fmoles of DNA probe. Plasmid pUbx HIII $\Delta 5-201$, used for footprinting the $U b x$ promoter, has been described previously (Biggin and Tjian 1988). The plasmid (termed p83b) containing the $D d c$ promoter was constructed by subcloning an EcoRI fragment from p1224 (a kind gift of J. Hirsh) into EcoRI-cut pUC119. p83b was cleaved with NcoI, $5^{\prime}$-end-labeled, and digested with EcoRI. The plasmid containing the $f t z$ neurogenic element (pFBR SK + ) was a kind gift from Yasushi Hiromi. The probe was constructed by cleaving this plasmid with $\mathrm{XbaI}$ and 5 '-end-labeling it, followed by a PvuII digestion.

\section{Isolation of recombinant clone encoding NTF-1}

The oligonucleotide 5'-ATGCT ITACG TICGI CAGGAGAACG AGGAG GTITA CACCC CCCTI-3' (where I represents inosine) was deduced from $\mathrm{CNBr}$ peptide 2, according to Lathe (1985). This oligonucleotide was 5 '-end-labeled with $\left[\gamma^{-32} \mathrm{P}\right]$ ATP and polynucleotide kinase and used to screen an amplified Drosophila 9- to 12-hr embryo cDNA library in $\lambda$ gtl1, which was kindly provided by Kai Zinn. $\lambda$ Plaques were transferred to nitrocellulose and screened as described by Kadonaga et al. (1987), except that final washes were done with $2 \times \mathrm{SST}, 0.5 \% \mathrm{SDS}$ at $59^{\circ} \mathrm{C}$. Two clones were isolated, and the cDNA insert of the longer one was subcloned into the SmaI site of pBluescript SK ${ }^{+}$(Stratagene) (plasmid termed pBS-NTF-112). The entire NTF-1 cDNA was sequenced on both strands using subclones generated by exonuclease III/Sl digestion. Sequencing was performed by the dideoxy method using Sequenase reagents (U.S. Biochemical).

\section{Northern blot analysis}

Northern blot analysis was performed essentially as described (Hauser et al. 1985), except that the NTF-1 probe was prepared by random hexamer priming (Amersham). Each lane contained $20 \mu \mathrm{g}$ of total RNA (kindly provided by Yasushi Hiromi). The actin probe was prepared by random hexamer priming of a HindIII-cut subclone of actin described previously (Fyrberg et al. 1980).

\section{In situ hybridizations to RNA}

For visualization with ${ }^{35}$ S-containing probes, Canton-S embryos were fixed, embedded in paraffin, sectioned, and prepared for hybridization essentially as described by Ingham et al. (1985). Plasmids pBS-NTF-1-12 and pBS-NTF-1-12' (containing the NTF-1 insert in either orientation) were used to synthesize RNA probes from the T7 promoter (Stratagene RNA Transcription Kit) to make single-stranded probes complementary and noncomplementary to the NTF- 1 transcript. These probes were hydrolyzed to an average length of $\sim 100$ nucleotides by incubation for $120 \mathrm{~min}$ at $\mathrm{pH} 10.4$ at $60^{\circ} \mathrm{C}$ (Cox et al. 1984). Hybridization, washes, and autoradiography were carried out according to the method of Ingham et al. (1985). The autoradiographs were exposed for 5 days. Two-week exposures of control slides, which were hybridized with the noncomplementary RNA probes, showed no signal above background.

The digoxigenin-labeled (Boehringer-Mannheim) singlestranded DNA probe of NTF-1 was made using polymerase chain reaction (PCR), according to the procedure of N. Patel (pers. comm.). In situ localization with the digoxigenin-containing probe was performed, based on the protocol of C. Pfeifle and D. Tautz (pers. comm.). Four- to twelve-hour embryos were fixed as described previously (Ingham et al. 1985) and treated with proteinase $\mathrm{K}$ prior to hybridization. Hybridization of the digoxigenin-labeled probe to embryos was based on the protocol of Mahoney and Lengyel (1987), whereas incubation of embryos with an anti-digoxigenin antibody conjugated to alkaline phosphatase and signal development were performed based on protocols of Boehringer-Mannheim.

\section{Expression of NTF-1 in HeLa cells}

The NTF-1 mammalian cell vector, termed vv-NTF-1, was constructed by cleaving pBS-NTF-1-12 with Asp718 and XbaI (in Bluescript polylinker), filling-in ends with Klenow fragment, and subcloning the fragment into a SmaI-cut vaccinia expression vector (pAbT4537, kindly provided by Applied bioTechnology, Inc.). Recombinant virus was generated essentially as described (Chakrabarti et al. 1985). HeLa cells at a density of $6.4 \times 10^{8}$ cells per liter were infected at a multiplicity of infection of 1.0 with the recombinant virus, and infection was allowed to proceed for $48 \mathrm{hr}$; an infection was conducted in parallel with a New York City Board of Health strain of vaccinia (kindly provided by Applied bioTechnology). HeLa nuclear extracts were prepared essentially as described for the preparation of Kc nuclear extracts (Parker and Topol 1984), except that buffers $\mathrm{A}$ and $\mathrm{B}$ contained $1 \mathrm{mM}$ sodium metabisulfite and 0.2 mM phenylmethylsulfonyl fluoride (PMSF), and buffer C contained these reagents at half of this concentration. DNA affinity chromatography on crude extracts $(5 \mathrm{mg} / \mathrm{ml})$ was performed as described above.

\section{Acknowledgments}

We thank Todd Laverty for help with in situ hybridizations to polytene chromosomes, Nipam Patel for assistance with the digoxigenin-based in situ hybridizations, and Yash Hiromi and Steve Jackson for gifts of plasmids containing the $f t z$ neurogenic element and for plasmid p83b, respectively. We thank Yash Hiromi for suggesting the ftz DNA-binding studies. We also thank all of the members of the Tjian lab and Irma Sanchez for helpful comments on the manuscript and encouragement; it was substantially improved by comments from Timothy Hoey, Richard Turner, Trevor Williams, Mark Biggin, and Al Courey. We also thank Gina Dailey and Karen Perkins for the gift of embryo extracts and Bruce England for help with cloning. We thank Karen Ronan for typing the manuscript and for help with figure design. B.D.D. is a recipient of an H.H.M.I. graduate student fellowship. M.F. was supported by a SERC (UK)/NATO postdoctoral fellowship. This work was partly funded by a grant from the National Institutes of Health (CA25417) to R.T.

\section{Note added in proof}

During the preparation of this manuscript, we received data from J. Hirsh documenting the cloning of a cDNA (elf-1) whose 
sequence closely matches that of NTF-1. The cDNA was isolated independently by screening a Drosophila expression library with monoclonal antibodies. It is of interest to note that NTF-1 lacks 31 amino acids at the carboxy-terminal end of the protein, which elf- 1 appears to possess, suggesting that the two forms were generated by alternative splicing. We thank J. Hirsh for sharing his data with us before publication. These findings were published recently (Bray et al. 1989).

The DNA sequence of NTF-1 will be submitted to the EMBL/GenBank data libraries.

\section{References}

Beachy, P.A., M.A. Krasnow, E.R. Gavis, and D.S. Hogness. 1988. An Ultrabithorax protein binds sequences near its own and the Antennapedia P1 promoters. Cell 55: 10691081.

Beall, C.J. and J. Hirsh. 1987. Regulation of the Drosophila dopa decarboxylase gene in neuronal and glial cells. Genes Dev. 1: $510-520$.

Berg, J. 1986. Potential metal-binding domains in nucleic acid binding proteins. Science 232: 485-487.

Bienz, M., G. Saari, G. Tremml, J. Muller, B. Zust, and P. Lawrence. 1988. Differential regulation of Ultrabithorax in two germ layers of Drosophila. Cell 53: 567-576.

Biggin, M.D. and R. Tjian. 1988. Transcription factors that activate the Ulbrabithorax promoter in developmentally staged extracts. Cell 53: 699-711.

Biggin, M.D., S. Bickel, M. Benson, V. Pirrotta, and R. Tjian. 1988. Zeste encodes a sequence-specific transcription factor that activates the Ultrabithorax promoter in vitro. Cell 53: 713-722.

Blochlinger, K., R. Bodmer, J. Jack, J.Y. Jan, and Y.N. Jan. 1988. Primary structure and expression of a product from cut, a locus involved in specifying sensory organ identity in Drosophila. Nature 333: 629-635.

Bohmann, D., A. Admon, D.R. Turner, and R. Tjian. 1988. Transcriptional regulation by the AP-1 family of enhancerbinding proteins: A nuclear target for signal transduction. Cold Spring Harbor Symp. Quant. Biol. 53: 695-700.

Bray, S.J., W.A. Johnson, J. Hirsh, U. Heberlein, and R. Tjian. 1988. A cis-acting element and associated binding factor required for CNS expression of the Drosophila melanogaster dopa decarboxylase gene. EMBO /. 7: 177-188.

Bray, S.J., B. Burke, N.H. Brown, and J. Hirsh. 1989. Embryonic expression pattern of a family of Drosophila proteins that interact with a central nervous system regulatory element. Genes Dev. 3: 1130-1145.

Campos-Ortega, J.A. and V. Hartenstein. 1985. The embryonic development of Drosophila melanogaster. Springer-Verlag, Berlin.

Caudy, M., H. Vassin, M. Brand, R. Tuma, L.Y. Jan, and Y.N. Jan. 1988. daughterless, A Drosophila gene essential for both neurogenesis and sex determination, has sequence similarities to myc and the achaete-scute complex. Cell 55: $1061-1067$.

Chakrabarti, S., K. Brechling, and B. Moss. 1985. Vaccinia virus expression vector: Coexpression of $\beta$-galactosidase provides visual screening of recombinant virus plaques. Mol. Cell. Biol. 5: 3403-3409.

Courey, A.J. and R. Tjian. 1988. Analysis of $\mathrm{Spl}$ in vivo reveals multiple transcriptional domains, including a novel glutamine-rich activation motif. Cell 55: 887-898.

Courey, A.J., D.A. Holtzman, S.P. Jackson, and R. Tiian. 1989. Cell (in press).

Cox, K.H., D.V. Deleon, L.M. Angerer, and R.C. Angerer. 1984. Detection of mRNAs in sea urchin embryos by in situ hybridization using asymmetric RNA probes. Dev. Biol.
101: $485-502$.

Davis, R.L., H. Weintraub, and A.B. Larsow. 1987. Expression of a single transfected cDNA converts fibroblasts to myoblasts. Cell 51: $987-1000$.

Fyrberg, E.A., K.L. Kindle, N. Davidson, and A. Sodja. 1980. The actin genes of Drosophila: A dispersed multigene family. Cell 19: 365-378.

Gill, G. and M. Ptashne. 1987. Mutants of GAL4 protein altered in an activation function. Cell 51: 121-126.

Hauser, C.A., A.L. Joyner, R.D. Klein, T.K. Learned, G.R. Martin, and R. Tjian. 1985. Expression of homologous homeo-box-containing genes in differentiated human teratocarcinoma cells and mouse embryos. Cell 43: 19-28.

Heberlein, U., B. England, and R. Tjian. 1985. Characterization of Drosophila transcription factors that activate the tandem promoters of the alcohol dehydrogenase gene. Cell 41: 965977.

Hiromi, Y., A. Kuroiwa, and W.J. Gehring. 1985. Control elements of the Drosophila segmentation gene fushi tarazu. Cell 43: 603-613.

Hope, I.A. and K. Struhl. 1986. Functional dissection of a eukaryotic transcriptional activator protein, GCN4, of yeast. Cell 46: 885-894.

Ingham, P.W. 1988. The molecular genetics of embryonic pattern formation in Drosophila. Nature 335: 25-33.

Ingham, P.W., K.R. Howard, and D. Ish-Horowicz. 1985. Transcription pattern of the Drosophila segmentation gene hairy. Nature 318: 439-445.

Jones, K.A., K. Yamamoto, and R. Tjian. 1985. Two distinct transcription factors bind to the HSV thymidine kinase promoter in vitro. Cell 42: 559-572.

Kadonaga, J.T. and R. Tjian. 1986. Affinity purification of sequence-specific DNA-binding proteins. Proc. Natl. Acad. Sci. 83: 5889-5893.

Kadonaga, J.T., K.R. Carner, F.R. Masiarz, and R. Tjian. 1987. Isolation of cDNA encoding transcription factor $\mathrm{Spl}$ and functional analysis of the DNA binding domain. Cell 51: 1079-1090.

Lathe, R. 1985. Synthetic oligonucleotide probes deducted from amino acid sequence data: Theoretical and practical considerations. J. Mol. Biol. 183: 1-12.

Ma, J. and M. Ptashne. 1987. Deletion analysis of GAL4 defines two transcriptional activating segments. Cell 48: 847-853.

Mahoney, P.A. and J.A. Lengyel. 1987. The zygotic segmentation mutant tailless alters the blastoderm fate map of the Drosophila embryo. Dev. Biol. 122: 464-470.

McGinnis, W., R.L. Garber, J. Wirz, A Kuroiwa, and W.J. Gehring. 1984. A homologous protein-coding sequence in Drosophila homeotic genes and its conservation in other metazoans. Cell 37: 403-408.

Murre, C., P.S. McCaw, and D. Baltimore. 1989. A new DNA binding and dimerization motif in immunoglobulin enhancer binding, daughterless, Myo D, and myc proteins. Cell 56: 777-783.

Parker, C.S. and J. Topol. 1984. A Drosophila RNA polymerase II transcription factor contains a promoter-region-specific DNA-binding activity. Cell 36: 357-360.

Patel, N.H., B. Schafer, C.S. Goodman, and R. Holmgren. 1989. The role of segment polarity genes during Drosophila neurogenesis. Genes Dev. 3: 890-904.

Perkins, K.K., G.M. Dailey, and R. Tjian. 1988. In vitro analysis of the Antennapedia P2 promoter: Identification of a new Drosophila transcription factor. Genes Dev. 2: 1615-1626.

Pirrotta, V., S. Bickel, and C. Mariani. 1988. Developmental expression of the Drosophila zeste gene and localization of zeste protein on polytene chromosomes. Genes Dev. 2: $1839-1850$. 
Santoro, C., N. Mermod, P.C. Andrews, and R. Tjian. 1988. A family of human CCAAT-box-binding proteins active in transcription and DNA replication: Cloning and expression of multiple cDNAs. Nature 334: 218-224.

Schneuwly, S., A. Kuroiwa, P. Baumgartner, and W.J. Gehring. 1986. Structural organization and sequence of the homeotic gene Antennapedia of Drosophila melanogaster. EMBO $J$. 5: 733-739.

Scholnick, S.B., S.J. Bray, B.A. Morgan, C.A. McCormick, and J. Hirsh. 1986. CNS and hypoderm regulatory elements of the Drosophila melanogaster dopa decarboxylase gene. Science 234: 998-1002.

Scott, M.P. and A.J. Weiner. 1984. Structural relationships among genes that control development: Sequence homology between the Antennapedia, Ultrabithorax, and fushi tarazu loci of Drosophila. Proc. Natl. Acad. Sci. 81: 4115-4119.

Soeller, W.C., S.J. Poole, and T. Kornberg. 1988. In vitro transcription of the Drosophila engrailed gene. Genes Dev. 2: $68-81$.

Thisse, B., C. Stoetzel, C. Gorostiza-Thisse, and F. PerrinSchmitt. 1988. Sequence of the twist gene and nuclear localization of its protein in endomesodermal cells of early Drosophila embryos. EMBO I. 7: 2175-2183.

Treizenberg, S.J., K.L. LaMarco, and S.L. McKnight. 1988. Evidence of DNA: Protein interactions that mediate HSV-1 immediate early gene activation by VP16. Genes Dev. 2: 730742 .

Villares, R. and C.V. Cabrera. 1987. The achaete-scute gene complex of $D$. melanogaster: Conserved domains in a subset of genes required for neurogenesis and their homology to myc. Cell 50: 415-424.

Williams, T., A. Admon, B. Luscher, and R. Tjian. 1988. Cloning and expression of AP-2, a cell-type-specific transcription factor that activates inducible enhancer elements. Genes Dev. 2: 1557-1569.

Wright, W.E., D.A. Sassoon, and V.K. Lin. 1989. Myogenin, a factor regulating myogenesis has a domain homologous to Myo D. Cell 56: 607-617. 


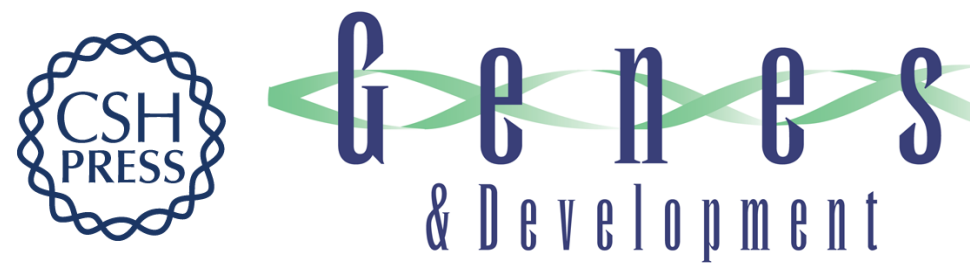

\section{Functional analysis of NTF-1, a developmentally regulated Drosophila transcription factor that binds neuronal cis elements.}

B D Dynlacht, L D Attardi, A Admon, et al.

Genes Dev. 1989, 3:

Access the most recent version at doi:10.1101/gad.3.11.1677

References This article cites 45 articles, 14 of which can be accessed free at:

http://genesdev.cshlp.org/content/3/11/1677.full.html\#ref-list-1

License

Email Alerting

Service

Receive free email alerts when new articles cite this article - sign up in the box at the top right corner of the article or click here.

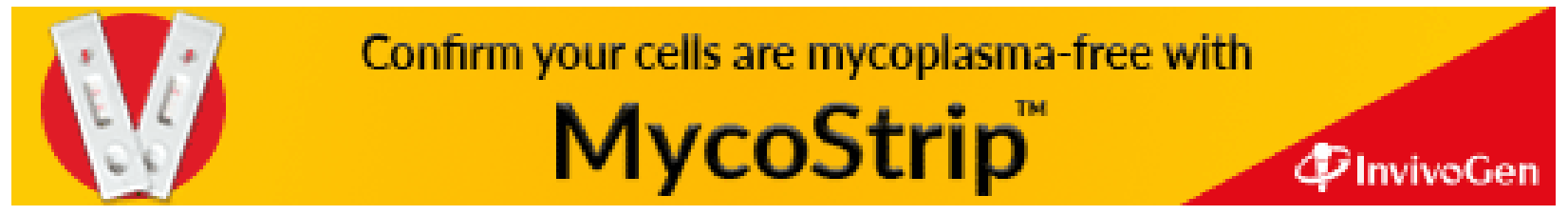

